\title{
Improved Efficiency for Quantitative and Qualitative Indexing for Citrus tristeza virus and Citrus psorosis virus
}

\author{
C. Rosa, Department of Plant Pathology, University of California, Davis 95616; M. Polek, California Citrus Tristeza \\ Eradication Agency, Tulare 93224; and B. W. Falk and A. Rowhani, Department of Plant Pathology, University of \\ California, Davis 95616
}

\begin{abstract}
Rosa, C., Polek, M., Falk, B. W., and Rowhani, A. 2007. Improved efficiency for quantitative and qualitative indexing for Citrus tristeza virus and Citrus psorosis virus. Plant Dis. 91:10891095 .

Reverse transcription-polymerase chain reaction (RT-PCR) assays were developed for the detection of Citrus tristeza virus (CTV; genus Closterovirus) and Citrus psorosis virus (CPsV; genus Ophiovirus) in citrus trees. Real-time TaqMan RT-PCR was also developed for the detection of CTV. Three different sample preparation methods were compared. The total RNA extraction method by Qiagen was found to be more reliable than the other two methods consisting of crude plant sap extraction and total nucleic acid trapping on a silica bed. Of 287 samples tested for CTV, 210 samples tested positive by RT-PCR and 198 samples by enzyme-linked immunosorbent assay (ELISA). Furthermore, the results from monthly tests of a selected number of fieldgrown CTV-infected trees showed that RT-PCR detected the virus in $100 \%$ of the infected trees in winter and summer, whereas ELISA did not. The one-tube RT-PCR detection was developed for $\mathrm{CPsV}$ and was more sensitive than ELISA. Notably, three of $10 \mathrm{CPsV}$ isolates were not detected by ELISA. As demonstrated here, our approach allows the efficacious detection of different viruses in citrus plants using a minimal amount of tissue during all seasons. The molecular methods described could be used in citrus certification programs and to test trees in nurseries and commercial orchards.
\end{abstract}

Citrus is one of the most economically important crops grown in Mediterranean climate regions of the United States and other parts of the world. Citrus production in the United States reached 16.4 million tons during the 2003-2004 seasons, (U.S. Department of Agriculture Economic Research Service, online publication) and California was responsible for $18 \%$ of the total U.S. production. Among the different diseases that can affect citrus trees, some of those caused by plant viruses are extremely important, since no cures are available and the diseased trees often must be eradicated. In California, the Central California Tristeza Eradication Agency (CCTEA, Tulare, CA) continuously monitors commercial citrus plantings for Citrus tristeza virus (CTV; family Closteroviridae, genus Closterovirus) (8), and now is interested in testing for the presence of Citrus psorosis virus (CPsV; genus Ophio-

Corresponding author: Adib Rowhani

E-mail: akrowhani@ucdavis.edu

Accepted for publication 23 March 2007.

doi:10.1094/PDIS-91-9-1089

(C) 2007 The American Phytopathological Society virus) (8). The Citrus Clonal Protection Program (CCPP) provides nurseries and growers with citrus nursery material certified as disease-free as a primary strategy for preventing virus diseases.

The tools used to detect CTV, CPsV, and other pathogens in citrus trees are mainly based on using indicator plants and on laboratory tests $(15,22,23,26,36)$ including enzyme-linked immunosorbent assay (ELISA) $(9,16,24,29,31,39)$. The drawbacks of these methods include: the time necessary for symptom development on indicator hosts, the cost of growing and maintaining the indicator plants, the antigenic properties of the pathogens to be detected, and variations in the sensitivity/accuracy of the tests. The latter is especially crucial for viruses such as CTV that have many variants $(7,13,18,23,35,37)$, are often accompanied by defective RNA $(2,6,19,20)$, and whose titer fluctuates during the year (17). In addition, certain mandarin varieties of citrus yield elevated ELISA results periodically during the year even when healthy (30). Considerable effort has been made during the last 10 years to develop and apply other more reliable, less expensive, and more sensitive molecular methods $(25,27)$, including reverse transcription-polymerase chain reac- tion (RT-PCR) $(5,9,11,12,14,21)$ and its application for strain identification (10), multiplex PCR (34), and more recently real-time RT-PCR (28). However, even with the significant improvements in these technologies and their decreasing costs, these approaches have so far not been generally accepted by regulatory agencies of the citrus industry.

Today, due to the availability of increasing numbers of genomic sequences of virus (and other pathogens) from every part of the globe and their availability in public databases, reliable systems were designed to detect CTV and CPsV by conventional RT-PCR, and CTV by highthroughput real-time RT-PCR. Further objectives of this research were to establish and compare different protocols for nucleic acid extraction from citrus tissues, to determine their effectiveness in relation to their sensitivity and costs, to test the developed system on a large number of citrus trees over a 1-year period, and finally, to compare the results with those of the established ELISA currently used at the CCTEA.

\section{MATERIALS AND METHODS}

Plant materials and reagents. In order to know when CTV titer was adequate for sample collection, the CCTEA has been collecting leaf samples on a weekly basis from known-infected field trees since 1993. Samples are tested by indirect double-antibody sandwich ELISA (DAS-IELISA). Extreme fluctuations occur in virus titer due to weather conditions (17); a drop in detectable virus occurs during the hot, dry summers and the relatively cold winters of the San Joaquin Valley of California. Beginning in January 2004, sideby-side comparisons of ELISA and RTPCR methods were performed using leaf tissue collected from the titer test trees of the CCTEA. Leaf tissue was collected in four field locations, three in Tulare County and one in Fresno County (CA) as well as from trees grown within environmentally controlled greenhouses and outdoor trees planted at the Agency. Eight leaves (with attached petioles) were collected from the four sides of each tree in order to minimize problems due to uneven virus distribution. 
Samples, including known CTV-positive and -negative controls, were sent blind to the University of California, Davis each month. The ELISA tests were performed at the CCTEA, whereas the RT-PCR analyses were conducted at the University of California, Davis (Table 1).

Eighteen mandarin trees were sampled and analyzed in March 2005. Twelve were field trees planted at the University of California, Lindcove Research and Extension Center (UC-LREC). Six were located at the CCTEA, five planted outdoors and one maintained under greenhouse conditions. Bioassays were performed by selecting buds from eight of the LREC trees and chip-inoculating them into 24 indicator plants of Mexican lime (Citrus aurantifolia). The indicator hosts were then tested by RT-PCR and real time RT-PCR in November 2005.

A sampling procedure similar to the one used for CTV was used for CPsV. Variable numbers of leaf/petiole samples were collected and tested monthly over 1 year. The samples were collected from inoculated plants grown under controlled greenhouse conditions. The sources of CPsV included greenhouse indicator plants graft-inoculated with known sources of different $\mathrm{CPsV}$ variants and healthy controls (Table 2). In addition, material was analyzed from plants that were part of a registration testing program for citrus nurseries. $\mathrm{CPsV}$ P203 and P213 variants (severe and mild, respectively) $(9,32)$ were graft inoculated onto indicator hosts, $C$. sinensis cv. Madame Vinous, with 20 replicate plants per isolate. Indicators were observed for symptom appearance and tested by RT-PCR at 21, 42, and 63 days after inoculation.

Sample preparation. Three methods for sample preparation for RT-PCR were compared. Each sample was divided into three parts, and one was used for each extraction method. For method $1,0.2 \mathrm{~g}$ of petioles were ground in $2.0 \mathrm{ml}$ of the guanidine isothiocyanate buffer (Qiagen RNeasy extraction kit) containing $1 \%$ sodium metabisulfite. Five hundred microliters of the extract was mixed with $70 \mu \mathrm{l}$ of $20 \%$ sarkosyl, and the solution was heated at $70^{\circ} \mathrm{C}$ for $10 \mathrm{~min}$. The supernatant was then processed as described in the Qiagen kit protocol, without further modifications. In method $2,0.25 \mathrm{~g}$ of tissue from the same citrus leaves as used for method 1 was ground in $5.0 \mathrm{ml}$ of a carbonate-based buffer (28) containing $1 \%$ sodium metabisulfite. Four microliters of the solution was removed and added to 50 $\mu \mathrm{l}$ of a glycine-based buffer (28), heated at $95^{\circ} \mathrm{C}$ for $10 \mathrm{~min}$, and immediately chilled on ice. Method 3 was only used occasion-

Table 2. Comparison between enzyme-linked immunosorbent assay (ELISA) and reverse transcription-polymerase chain reaction (RT-PCR) for the detection of different Citrus psorosis virus (CPsV) isolates $^{\mathrm{a}}$

\begin{tabular}{lllcc}
\hline $\begin{array}{c}\text { CPsV } \\
\text { isolate }\end{array}$ & Symptoms & Isolate source & $\begin{array}{c}\text { ELISA } \\
\text { results }^{\text {b }}\end{array}$ & $\begin{array}{c}\text { RT-PCR } \\
\text { results }\end{array}$ \\
\hline P-201 & Leaf yellowing, shock symptoms & Rubidoux & $\mathrm{N}$ & $\mathrm{P}$ \\
P-202 & Severe shock, severe leaf symptoms & Rubidoux & $\mathrm{N}$ & $\mathrm{P}$ \\
P-203 & Severe shock, severe leaf symptoms & Rubidoux & $\mathrm{P}$ & $\mathrm{P}$ \\
P-205 & Severe shock, severe leaf symptoms & NGR2074 & $\mathrm{P}$ & $\mathrm{P}$ \\
& & R. Kruegar & & \\
P-208 & Shock and moderate to severe leaf symptoms & Rubidoux & $\mathrm{N}$ & $\mathrm{P}$ \\
P-209 & Severe shock, moderate leaf symptoms & Rubidoux & $\mathrm{P}$ & $\mathrm{P}$ \\
P-212 & Mild shock, moderate leaf symptoms & Rubidoux & $\mathrm{P}$ & $\mathrm{P}$ \\
P-213 & Mild shock and moderate leaf symptoms & Rubidoux & $\mathrm{P}$ & $\mathrm{P}$ \\
P-216 M & Severe shock, severe leaf symptoms & Rubidoux & $\mathrm{P}$ & $\mathrm{P}$ \\
P-250-3 & Severe shock, mild leaf symptoms, & NGR3455 & $\mathrm{P}$ & $\mathrm{P}$ \\
& yellowing/bark lesion & R. Kruegar & & \\
\hline
\end{tabular}

${ }^{a}$ All the CPsV isolates were maintained on Citrus sinensis cv. Madame Vinous plants in the greenhouse.

${ }^{b}$ Plants were maintained at the Central California Tristeza Eradication Agency (CCTEA). Samples were collected and divided into two parts. ELISA tests were done at the CCTEA and RT-PCR analyses were done at UC Davis. $\mathrm{N}=$ negative, $\mathrm{P}=$ positive for $\mathrm{CPsV}$.

${ }^{\mathrm{c}}$ Rubidoux $=$ University of California, Riverside, Citrus Clonal Protection Program.

Table 1. Comparison between enzyme-linked immunosorbent assay (ELISA) and reverse transcription-polymerase chain reaction (RT-PCR) for the detection of Citrus tristeza virus ${ }^{\mathrm{a}}$

\begin{tabular}{|c|c|c|c|c|c|}
\hline Scion/rootstock & Trees tested $^{b}$ & $\begin{array}{l}\text { Total samples } \\
\text { in 1-year period }\end{array}$ & $\begin{array}{c}\text { Positive } \\
\text { by ELISA }\end{array}$ & $\begin{array}{c}\text { Positive } \\
\text { by RT-PCR }\end{array}$ & Location \\
\hline $\begin{array}{l}\text { Citrus reticulata } \text { (Fina-sodea)/ } \\
\text { C. sinensis } \times \text { Poncirus trifoliata (Carrizo citrange) }\end{array}$ & 3 & 22 & 0 & 2 & $\begin{array}{l}2 \text { greenhouse and } \\
1 \text { outside CCTEA }\end{array}$ \\
\hline $\begin{array}{l}\text { C. reticulata } \times \text { C. paradisi (Minneola)/ } \\
\text { C. aurantium (sour orange) }\end{array}$ & 1 & 4 & 2 & 4 & Greenhouse \\
\hline C. sinensis (Valencia)/unknown & 1 & 11 & 0 & 1 & Commercial grove \\
\hline C. sinensis (navel)/unknown & 2 & 24 & 24 & 24 & Commercial groves \\
\hline C. sinensis (Madame Vinous) & 20 & 88 & 84 & 88 & $\begin{array}{l}\text { Greenhouse CTV } \\
\text { collection }\end{array}$ \\
\hline $\begin{array}{l}\text { C. reticulata }(\text { Pixie }) / \\
(\text { C. sinensis } \times \text { P. trifoliata }(\text { Carrizo citrange })\end{array}$ & 7 & 67 & 45 & 47 & Greenhouse \\
\hline C. medica (Etrog citron) & 2 & 12 & 10 & 11 & Greenhouse \\
\hline $\begin{array}{l}\text { C. reticulata }(\text { Sidi-aissa)/ } \\
\text { C. sinensis } \times P \text {. trifoliata }(\text { Carrizo citrange })\end{array}$ & 3 & 33 & 33 & 33 & Outdoors at CCTEA \\
\hline C. limon (Eureka)/ C. jambhiri (rough lemon) & 3 & 16 & 0 & 0 & Greenhouse \\
\hline $\begin{array}{l}\text { C. sinensis (Madame Vinous)/ } \\
\text { C. jambhiri (rough lemon) }\end{array}$ & 1 & 10 & 0 & 0 & Greenhouse \\
\hline Total & 43 & 287 & 198 & 210 & \\
\hline
\end{tabular}

${ }^{a}$ Number of different citrus trees, either seedlings or trees grafted onto rootstocks, were included in this study. Each tree was tested several times a year, ranging from 4 to 12 based on the location, collection schedule, and weather conditions.

${ }^{\mathrm{b}}$ Individual trees were sampled repeatedly during the course of these experiments. Samples were divided into two parts. One part was used for ELISA tests at the Central California Tristeza Eradication Agency (CCTEA) and the second part for RT-PCR at UC Davis. 
test for CTV. Alternatively, $5 \mu \mathrm{l}$ of the homogenate prepared in method 2 were spotted on Whatman membrane disks; the disks were placed in microfuge tubes containing the cocktail for RT-PCR and used directly in RT-PCR (28). Sets of the same membranes were tested at different times, the last being 13 months after samples were spotted. During that time, the membranes were stored in a paper folder at room temperature.

DAS-I-ELISA. The methodology used to test for CTV by ELISA was as outlined in the CCTEA Laboratory Procedures and Quality Assurance Manual. Microtiter plates were first coated with goat anti-CTV antibodies (produced at the University of California, Riverside) to trap the virus. Plant sap was extracted from approximately $1 \mathrm{~g}$ of leaf petioles by placing in 5 $\mathrm{ml}$ of PEP extraction buffer and homogenizing for $10 \mathrm{~s}$ in a KLECO Tissue Pulverizer (Kinetic Laboratory Equipment Company, Visalia, CA). The homogenates were loaded onto microtiter plates and incubated at $4{ }^{\circ} \mathrm{C}$ overnight. After washing, the plates were loaded with rabbit anti-CTV polyclonal antibody produced by Nikolaeva et al. (24) and incubated at $34^{\circ} \mathrm{C}$ for $2 \mathrm{~h}$. Plates were again washed. Goat anti-rabbit alkaline phosphatase conjugate (MP Biomedicals, Aurora, $\mathrm{OH}$ ) was added followed by a 2-h incubation at $34^{\circ} \mathrm{C}$. The plates were washed and the substrate $p$ nitrophenyl phosphate was added and incubated at room temperature. The plates were read at $405 \mathrm{~nm}$ using a Molecular Devices reader and Softmax Software. A positive reaction occurred within 1.5 to $2 \mathrm{~h}$ after the addition of the substrate.
The ELISA for CPsV was performed according to the protocols included in a commercially available test kit (AGRITEST SRL, Valenzano, Italy). This DASELISA uses monoclonal antibody alkaline phosphatase conjugate (hybridoma line Ps 29, DPPMA University of Bari, Italy). The signal develops by reaction with $p$ nitrophenyl phosphate within 4 to $4.5 \mathrm{~h}$.

ELISA data were presented as the average of the absorbance values obtained for four samples per replicate. Two wells each of positive and negative controls were included in each plate. The threshold level was calculated as two times the average of the absorbance value for the healthy control.

RT-PCR and real time RT-PCR. Onetube RT-PCR reactions were performed as described by Osman and Rowhani (28), using an annealing temperature of $58^{\circ} \mathrm{C}$, for both CTV and CPsV primers. The primer sequences used for CTV detection were the p20-forward/reverse and CPforward/reverse primers (13). The sequences of the primers used for $\mathrm{CPsV}$ were obtained from the most conserved region ( $\mathrm{CP}$ region from $\mathrm{CPsV}$ 'group $\mathrm{C}$ ') (1) of more than 20 sequences found in public databases. The primers sequences were: 5' TGAGGAA/GTTGAGCCATGC $3^{\prime}$ CPsV-forward and 5' CCATCTGGAGTGAGGCTGTA 3' CPsV-reverse. The size of the amplified product was $390 \mathrm{bp}$. The program used to align the viral sequences was Multiple Alignment in DNASIS MAX (MiraiBio, Hitachi).

A real-time one-tube RT-PCR protocol was also evaluated for CTV. The samples were the same as collected for the above surveys, and used in standard RT-PCR tests. Real-time RT-PCR reactions were performed as follows: 0.5 to $3.0 \mu \mathrm{l}$ of template was added to $12 \mu \mathrm{l}$ total reaction volume (28). The program was as follows: 1 cycle at $45^{\circ} \mathrm{C}$ for $35 \mathrm{~min}$ (reverse transcription), 1 cycle at $95^{\circ} \mathrm{C}$ for $10 \mathrm{~min}$ (denaturing), 50 cycles at $95^{\circ} \mathrm{C}$ for $15 \mathrm{~s}$, and $50-55$ cycles at $60^{\circ} \mathrm{C}$ for $1 \mathrm{~min}$ (amplification). The primer and probe sequences used in the real-time RT-PCR were designed on the most conserved regions from 74 sequences in the CTV major coat protein. The primer sequences were: CTV28F: 5' GTAGACGAAT/CCGCAATTT GAGTTAT 3' and CTV-158R: 5' TATG TACACAGCACATTCT/CAAATCAGTCA $3^{\prime}$. The size of the amplified product was $103 \mathrm{bp}$. The TaqMan probe was a minor groove-binding probe (TaqMan MGB Probes). The reporter dye conjugated at the 5 ' end of the probe (fluor) was Fam -490 (6-carboxyfluorescein), and a nonfluorescent quencher (NFQ) dye was conjugated at the $3^{\prime}$ end of the probe and its sequence was: CTV-109p: 5' ATTTCTTGACCG GAGCTG 3'.

\section{RESULTS}

RT-PCR. In initial experiments, we compared RT-PCR results for known healthy and CTV-infected samples using sample preparation methods 1,2 , and 3 . Method 1 yielded very good quality RNA that gave consistent results by RT-PCR Method 2 was easier and more economical, but required some adjustment to optimize the amount of template used in RTPCR reactions and minimize the effects of PCR enzyme inhibitors present in the plant

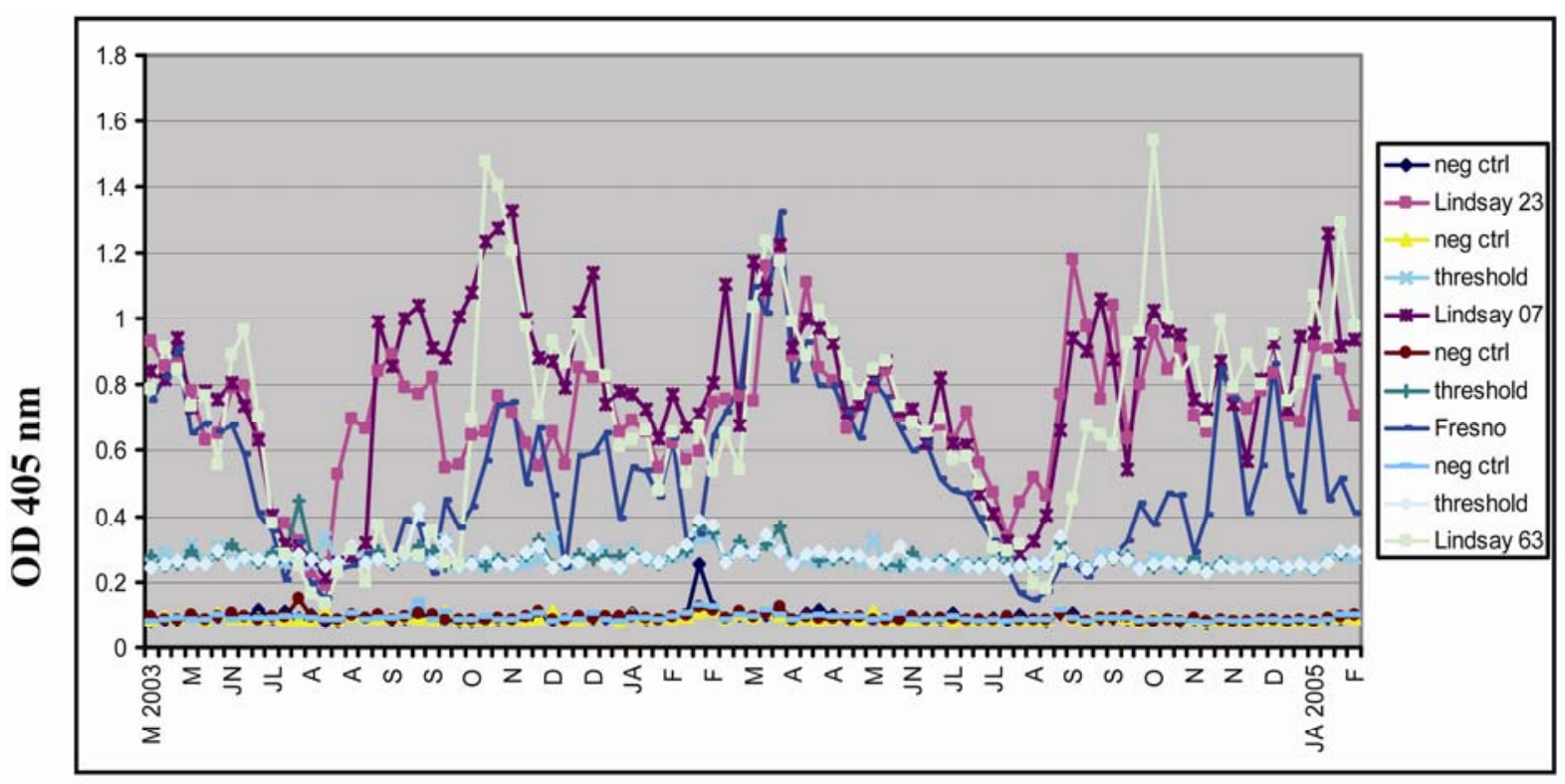

Time (months)

Fig. 1. Detection of Citrus tristeza virus (CTV) by indirect double-antibody sandwich enzyme-linked immunosorbent assay (DAS-I-ELISA): Absorbance values $\left(A_{405 \mathrm{~nm}}\right)$ of the trees tested from March 2003 to February 2005. Collections were performed over four field locations: three in Lindsay (23, 07, 63), Tulare County, and one in Fresno County, CA. The $A_{405 \mathrm{~nm}}$ values are reported on the Y axis as average of 4 to 5 trees, while collection months are reported on the $\mathrm{X}$ axis. Threshold values were calculated as twice the value of the negative controls. Negative control O.D. values were between 0.08 and 0.11 ; controls were collected in the same locations as the test trees. 
extract. However, the initial results showed that two of 94 samples tested as negative by method 2 were positive by method 1 (data not shown). Also, we found that samples extracted by method 1 could be stored for long periods ( $>1$ year) and gave consistently reproducible results, whereas CTV-positive samples prepared by method 2 could not be stored for more than 1 month without decreasing the ability to detect CTV. Method 3 was compared only on some samples; therefore, it was not included in the comparative analyses.

Nine healthy and 15 CTV-infected samples were tested using Whatman and Hybond $\mathrm{N}+$ membranes. Both proved to be useful for RT-PCR detection of CTV; in fact, when freshly prepared membranes were boiled and used for one-tube RTPCR, all the infected samples tested positive by RT-PCR and all healthy samples were negative (data not shown). To measure the longevity of the spotted membranes, sets of membranes were spotted and stored in a folder at room temperature and tested every month. After 2 months, five of the CTV-infected samples failed to give positive results. Nevertheless, when we tested the membranes for the last time 13 months after spotting, three infected samples still gave positive reactions.

Two sets of primers (P20 and CP) were tested for CTV detection, and both gave comparable results (data not shown). In subsequent experiments, we only used the CP primers.

Comparison between RT-PCR and ELISA in a time-course study. ELISA analysis showed that the ability to detect CTV consistently in citrus plants fluctuated over time (Fig. 1). The data indicated that ELISA absorbance values were higher during spring and fall and lower in winter and summer. In the warmer summer months, absorbance values were sometimes below the ELISA threshold (Fig. 1, Fresno in August), therefore producing false negative results. When RT-PCR and ELISA were compared on the same samples over time, more consistent results for CTV detection were obtained by using RTPCR, especially during the summer and

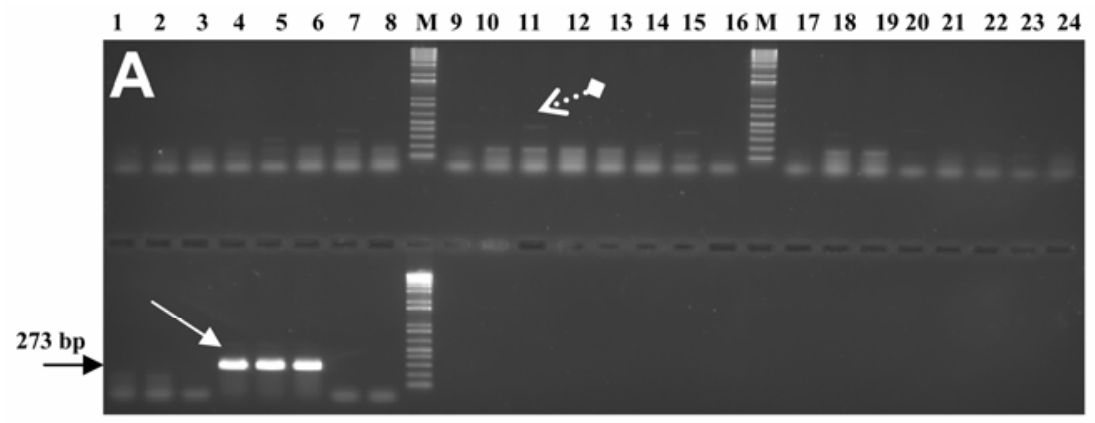

$\begin{array}{lllllllll}25 & 26 & 27 & 28 & 29 & 30 & 31 & 32 & \text { M }\end{array}$

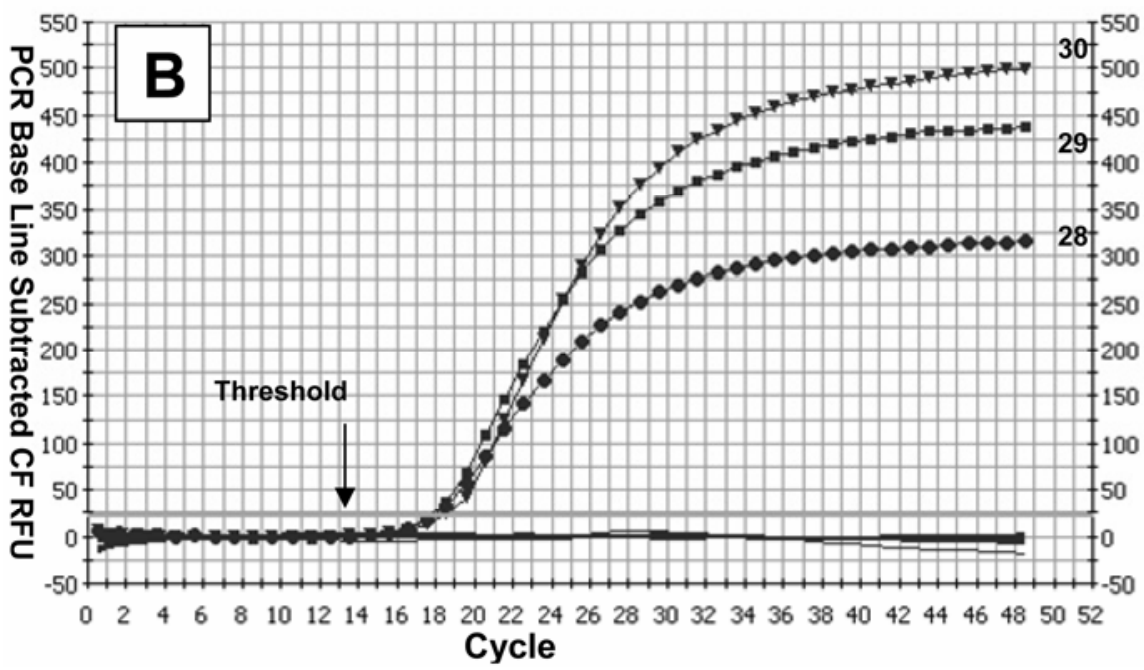

Fig. 2. A comparison between reverse transcription-polymerase chain reaction (RT-PCR) and realtime RT-PCR analysis for Citrus tristeza virus (CTV) detection. In this experiment, 32 orange trees, labeled 1 to 32, of unknown disease condition were tested. A, A 1.5\% agarose gel electrophoresis of RT-PCR products followed by staining with ethidium bromide and visualization on a UVtransilluminator. Solid arrows show CTV-positive samples, dashed arrows show nonspecific amplification. $\mathrm{M}$ is 1-kb Plus DNA ladder (Gibco, BRL). CP primers were used. B, A real time RT-PCR analysis of the same samples. Samples 28, 29, and 30 were positive in both tests. winter months. In 287 samples tested, RTPCR detected 210 CTV positives, whereas ELISA detected only 198 (Table 1). Thus, $4.2 \%$ more CTV-positive samples were detected by RT-PCR, indicating that this testing method is more sensitive than ELISA. Notably, this $4.2 \%$ value was the result of 1 year of analyses on field as well as greenhouse trees. If we were to base the comparison only on field trees and only during summer and winter months, greater differences would be shown to exist between the two methods. In addition, we observed that samples collected from the same tree at different times produced different test results. We believe that this inconsistency in test results is due to the virus distribution in the tree (Table 1). Overall sensitivity of RT-PCR versus ELISA was compared and showed that in winter and summer RT-PCR detected consistently $100 \%$ of the CTV-infected trees in the field, whereas ELISA did not (Fig. 1).

Real-time one-tube RT-PCR. A higher throughput and quantitative real-time RTPCR was evaluated and compared with standard RT-PCR for the detection of CTV in citrus trees. In this experiment, the RNA extracts from 32 samples for the months of September through March were tested. The same three samples from the total of 32 were positive by both methods (Fig. 2A and B). The RT-PCR was performed using primers $\mathrm{CP}$ (Fig. 2A) and P20 (data not shown). As shown in Figure 2A, faint nonspecific amplification products were observed in a few samples (lanes 5, 7, 11, 15, 18 , and 19), but the same samples were negative in real-time RT-PCR (Fig. 2B). In general, the results were comparable in both tests, but real-time RT-PCR produced clearer results. The three CTV positive samples had $\mathrm{Ct}$ (cycle threshold, cycle at which the samples pass the established threshold) values between 17 and 18, suggesting optimal RNA template quality. Negative controls always remained beneath the threshold. Samples prepared by method 1 gave more consistent and clearer results than those prepared by method 2 . (Fig. 3, Table 3). The CT values of samples prepared using method 1 were all lower than the same samples extracted by method 2. However, following adjustment of the template concentrations, all the CTV-positive samples extracted by method 2 showed clear amplification.

Mandarin trees $(C$. reticulata $)$ are known to be asymptomatic for CTV (38). Eighteen mandarin trees, known to be CTV negative based on indicator assays and ELISA, were selected and tested in March 2005 using ELISA and RT-PCR, and both gave inconsistent results. More precisely, RT-PCR occasionally showed faint, nonspecific products (lanes 2, 4, 9, and 18 in Fig. $3 \mathrm{~A}$ bottom panel, lanes 4 and 12 in Fig. 3B), and ELISA showed occasional low reactions. All the samples were tested by using both sets of primers: 
CP (data not shown) and P20 primers (Fig. $3 \mathrm{~A}$ and $\mathrm{B}$ ), and results were similar. Unlike the three CTV-positive (samples 13, 14, and 18) and the two negative controls (samples 15 and 17) grown in the greenhouse, the remaining samples were collected from field trees. The same trees were then tested by real-time RT-PCR, using extraction methods 1 and 2 . The majority of the tested trees produced higher CT values when compared to the positive controls, but all samples tested CTV positive. In general, field trees showed lower CTV titer than greenhouse trees, and all the CTV-positive controls showed consistent and clear amplification in RT-PCR and real-time RT-PCR. Eight of these CTV-positive mandarin samples were chip-inoculated into 24 Mexican lime indicator plants (three replicates each). The grafted indicator plants were tested by ELISA at 3, 4, and 8 months postinoculation and by real-time RT-PCR 8 months postinoculation (November 2005). ELISA and visual examination on all inoculated indicators were negative. However, 21 of the inoculated indicators were positive by real-time RT-PCR, and their $\mathrm{Ct}$ values ranged from 26.9 to 38.3 (average $35.2 \pm$ 2.8 ), indicative of marginal virus detection.
Finally, the real-time RT-PCR products (109 bp) were cloned, sequenced, and found to be $100 \%$ identical to CTV sequence.

Application to other viruses. We developed a one-tube RT-PCR assay to use for $\mathrm{CPsV}$ detection. In a comparison, 10 different $\mathrm{CPsV}$ isolates were tested by ELISA and RT-PCR (Table 2). Of these, only seven isolates were detected by ELISA, whereas RT-PCR detected all 10 isolates. In a different experiment, 39 trees that were inoculated with the 10 original isolates were tested. Only seven of the 39 trees were positive by ELISA and 24 were positive by RT-PCR. These results were confirmed by grafting onto indicator hosts. Moreover, 40 indicator plants were inoculated using CPsV strain 213 (mild) and 203 (severe), 20 plants per strain. At 3 weeks postinoculation, the indicator plants started to show symptoms and to test positive by RT-PCR. By 6 weeks postinoculation, $100 \%$ of the inoculated plants tested positive by RT-PCR. In general, the symptom appearance corresponded with the RTPCR results, although in a few cases the symptoms, i.e., "chlorosis", were not characteristic or diagnostic for CPsV. We also compared two kinds of RNA extraction
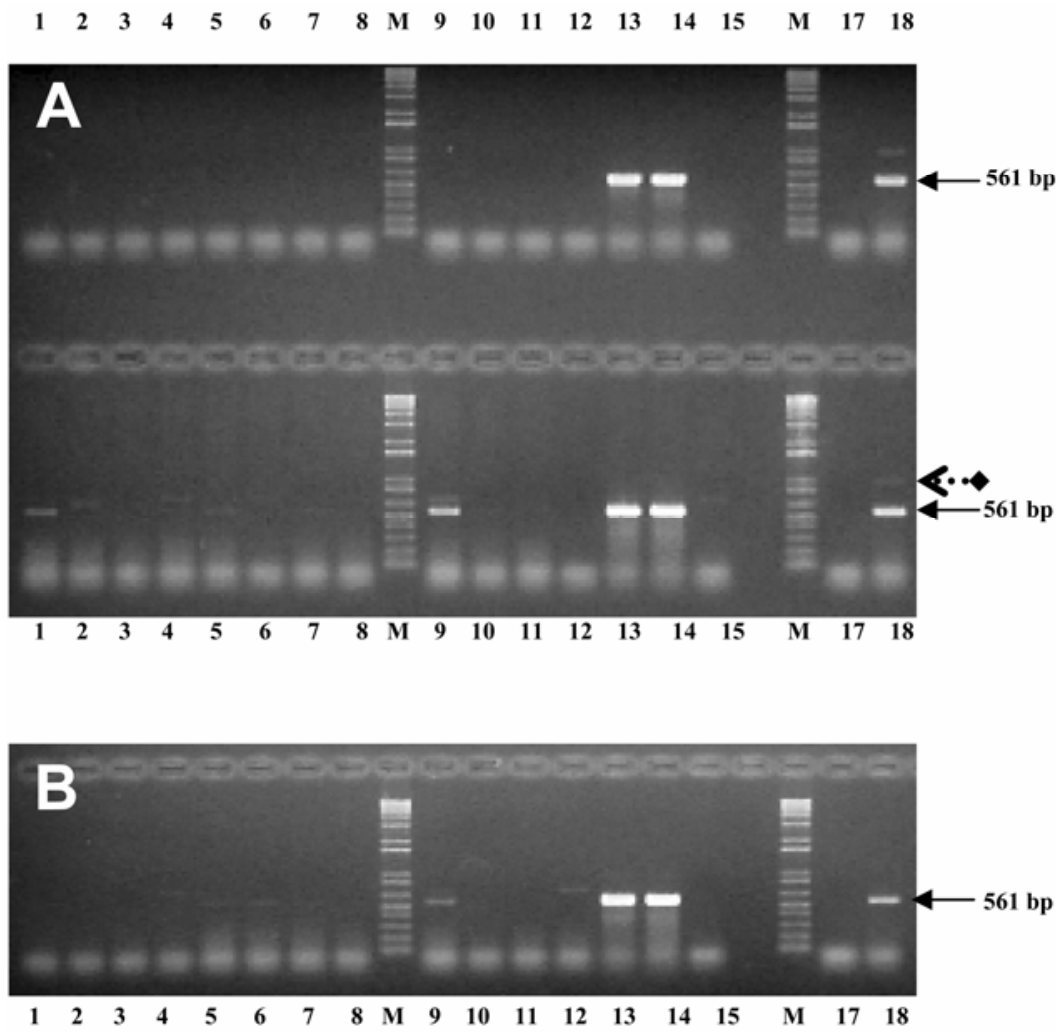

Fig. 3. Reverse transcription-polymerase chain reaction (RT-PCR) results on a $1.5 \%$ agarose gel used for the detection of Citrus tristeza virus (CTV) in mandarin trees. Samples were extracted using methods 1,2 , and 3 . In this experiment, 18 mandarin trees, labeled 1 to 18 , with unknown disease condition were tested. M is 1-kb Plus DNA ladder (Gibco, BRL). CTV P20 primers were used. A, Top panel: a gel shows the results of the samples from GES extractions (method 2). Lane numbers 13, 14, and 18 are positive. Bottom panel: same samples prepared by silica extraction (method 3). Numbers 1, 5, 7, 9, 13, 14, and 18 are positive, and their position is indicated by a solid arrow. A few other samples show faint and nonspecific bands (e.g., lane 4) and are indicated by the dashed arrow. B, Samples prepared by Qiagen extraction (method 1). Lane numbers 5, 6, 9, 13, 14, and 18 are positive. Many other samples show faint or nonspecific bands. Solid arrows show CTV-positive samples. (methods 1 and 2), and both methods gave comparable results, even if the concentration of template extracted by method 2 had to be lowered and adjusted to avoid the effect of PCR inhibitors. Finally, we tested 110 different citrus trees including nine trees from the CTV collection (at CCTEA), two trees from a grower orchard, and 99 from CDFA certified trees by RTPCR, and the results were compared with biological indexing on $C$. sinensis cv. Madame Vinous indicator plants. In this comparison, only four trees in the CTV collection that were showing psorosis symptoms tested positive by both methods.

\section{DISCUSSION}

In this paper, we report the nucleic acidbased approaches for the efficient detection of two important citrus viruses (CTV and $\mathrm{CPsV}$ ) in citrus plants. More importantly, we tested both field and greenhouse-grown plants, and for confidence we compared our data with ELISA and bioassay tests. Our data showed that RT- and real-time RT-PCR offer several advantages over the currently used procedures for both of these viruses in citrus trees.

CTV is the causal agent of the most important virus disease of citrus in California and most citrus-producing regions worldwide. The universal effective control strategy is to ensure that the propagation materials are $\mathrm{CTV}$-free $(3,4)$. This alone does

Table 3. Comparison of extraction methods 1 and 2 in real-time reverse transcription-polymerase chain reaction (RT-PCR) used for Citrus tristeza virus (CTV) detection

\begin{tabular}{lccc}
\hline & & \multicolumn{2}{c}{ Method 2 } \\
\cline { 3 - 4 } Samples & Method 1 & $\mathbf{( 4} \boldsymbol{\mu l})$ & $\mathbf{( 2} \boldsymbol{\mu l})$ \\
\hline A01 & 21.3 & N/A & 32.7 \\
A02 & 22.1 & N/A & 40.1 \\
A03 & N/A & N/A & N/A \\
A04 & 32.1 & N/A & N/A \\
C01 & 21.9 & 54.2 & 39.6 \\
C02 & 20.3 & 55.0 & 32.4 \\
C03 & 15.4 & 34.6 & 27.5 \\
C04 & N/A & N/A & N/A \\
D01 & 21.7 & N/A & 37.1 \\
D02 & 18.8 & 49.4 & 28.8 \\
D03 & 16.5 & N/A & 26.8 \\
D04 & 20.7 & 47.0 & 31.3 \\
E01 & 17.2 & 54.4 & 29.4 \\
E02 & 16.7 & 45.9 & 28.1 \\
E04 & 20.3 & N/A & 33.2 \\
F01 & 19.5 & N/A & 30.4 \\
F02 & 16.7 & 50.3 & 30.3 \\
F03 & 17.4 & 48.2 & 30.9 \\
F04 & 21.8 & 53.9 & 33.3 \\
G01 & 20.5 & 54.0 & 36.4 \\
G02 & 19.3 & 43.2 & 29.4 \\
G03 & 35.3 & N/A & N/A \\
G04 & 34.3 & N/A & N/A \\
H01 & 22.8 & N/A & 32.4 \\
H02 & 38.7 & N/A & N/A \\
H03 & 32.8 & N/A & N/A \\
\hline
\end{tabular}

a In method 2, two different volumes of the templates $(2 \mu \mathrm{l}$ and $4 \mu \mathrm{l})$ were compared. $\mathrm{Ct}$ value data are presented in the table.

${ }^{\mathrm{b}} \mathrm{N} / \mathrm{A}=$ samples with $\mathrm{Ct}$ values higher than 55 and considered negative. 
not give complete disease control, but accurate detection of CTV infections in propagation materials and field plants is essential to keep the disease under control.

In any testing program, it is important to consider the potential variability in the pathogen population, and how that variability may affect detection. No one strategy can ever be $100 \%$ accurate, but we used RT-PCR primers based on sequences that are highly conserved among known CTV sequences (13). Our data showed that we have been able to detect all CTV isolates that have been made available to us, and when sensitivity of testing procedures was compared, RT-PCR was more sensitive and consistent than ELISA. In our tests, we compared RT-PCR and ELISA on the same trees over a 1-year period and showed that ELISA values (and likely virus titer) fluctuated and most noticeably titer declined during the warm summer months. We found that CTV titers were sometimes below the ELISA threshold and often CTV-infected trees gave negative ELISA reactions during the California hot summer months. This decline in CTV titer was reported before (17), but the observations were never extended for such a long period of time (almost 2 years). In our data analysis, we observed that the virus titer drops, not only during summer, but also during winter. The drop in CTV titer might be correlated with the lack of plant growth that occurs in both seasons. This seems logical in the context of an intracellular obligate parasite that needs active cellular machinery to replicate effectively; nevertheless, this is the first time that data are available to support this hypothesis. However, the low virus titer proved not to be a problem for RT-PCR, as we still obtained positive results from these trees during the summer and winter months and we are confident that the $4.2 \%$ difference between ELISA and RT-PCR detection observed here will be even greater if the testing frequency were higher during summer months. Moreover, we also observed that the use of less RNA template (prepared by method 2) in the summer months $(\sim 0.5 \mu \mathrm{l}$ versus $2.0 \mu \mathrm{l}$ per RT-PCR) produced better results, suggesting that in addition to a decrease in CTV titer during these months, there may be an increase in RT-PCR enzyme inhibitors in citrus plants.

Because RT-PCR can be considered more technically demanding than ELISA, we evaluated ways to simplify tests and increase cost effectiveness. We found a relatively inexpensive and simple procedure to prepare high-quality templates useful for RT-PCR. Purified RNA prepared by RNeasy (Qiagen) extracts (method 1) was always the best, and we found that samples could be stored for very long periods at $-20^{\circ} \mathrm{C}$ and remain stable. However, simple crude extracts in carbonate buffer (method 2) and even samples spotted on Whatman paper or charged nylon membranes gave very good results and could be useful if not intended for long storage periods.

Real-time RT-PCR is another approach that gives qualitative and quantitative data and offers the opportunity to perform relatively high-throughput analyses. We used a one cocktail real-time RT-PCR and showed consistency and efficiency in the results. We obtained a higher quality RNA template when using method 1 , which resulted in a more consistent detection of CTV; therefore, the advantage of real-time RTPCR must be weighed versus the cost of sample extraction. Obviously, the efficiency of real-time RT-PCR compared with conventional RT-PCR is based on the logarithmic amplification of a shorter DNA sequence (in our case 130 bp versus 273 or $561 \mathrm{bp}$ in RT-PCR). The specificity of this amplification is ensured by the perfect matching of two primers and one probe to the target sequence. In our case, this was achieved by choosing the most conserved region of a multiple alignment of more than 70 sequences of CTV where there were only two nucleotide mismatches. This increased our confidence in proposing this set of primers and probes for efficient CTV detection.

CTV is not evenly distributed in citrus trees, and the virus can be composed of a number of sequence variants in a tree $(7,13,18,23,35,37)$. The relationship between different CTV variants and different host species is not clear yet. For example, mandarin cultivars are considered to be poor hosts for CTV (38). We do not know yet if CTV is not able to replicate at high levels in these hosts because the trees are virus-resistant, or if different CTV variants infect these trees. In fact, the product amplified by real-time RT-PCR that was sequenced was too short (130 bp) and conserved to provide the necessary information. However, the effect of these variants, after insect transmission (7), could be much more severe on other citrus hosts, and thus we think it is crucial to be able to detect low levels of viral infection, even on asymptomatic trees. In our experiments, we demonstrated that some mandarin trees, previously considered to be virus-free based on ELISA and indicator host data, were positive by real-time RT-PCR, and that the CTV variants could be transmitted by grafting to indicator hosts. Although biological indexing on an indicator host, Mexican lime, is a reliable test for CTV detection, the inoculated plants did not show symptoms but tested positive by real-time RT-PCR at a marginal level. Further studies are needed to investigate the possibility of the existence of a new CTV variant in mandarin varieties that is incapable of producing symptoms on the indicator host.

Current CPsV detection in California is based on ELISA and bioassay on indicator plants. The latter is mostly accurate but time-consuming and relatively expensive. We showed that RT-PCR is more accurate than commercially available ELISA tests for $\mathrm{CPsV}$ detection, and as accurate as bioassays. Compared to bioassays, RTPCR analyses for CPsV were much faster (1 day versus 2 months or longer) and therefore less expensive. We did find that high-quality RNA prepared by method 1 gave best results, as for CTV detection. On the other hand, membrane spotting, which worked well for CTV, did not work for CPsV.

Approximately $20 \mathrm{CPsV}$ nucleotide sequences are available in public databases. We chose these to design the set of PCR primers. To evaluate the effectiveness of our primers, we tested mild and severe variants of $\mathrm{CPsV}$, performed a survey on field trees, and found that these primers worked well in all the tests. However, sequences from more isolates are needed to design PCR primers to detect the wide range of $\mathrm{CPsV}$ isolates and provide more confidence in our testing program.

\section{ACKNOWLEDGMENTS}

This effort was supported in part by the University of California and a grant from the California Citrus Nursery Advisory Board. We also wish to acknowledge the excellent assistance of Cindy Wallen.

\section{LITERATURE CITED}

1. Alioto, D., Malfitano, M., Troisi, A., Peluso, A., Martin, S., Milne, R. G., Guerri, J., and Moreno, P. 2003. Variability of the coat protein gene of Citrus psorosis virus in Campania, southern Italy. Arch. Virol. 148:2155-2166.

2. Ayllon, M. A., Lopez, C., Navas-Castillo, J., Mawassi, M., Dawson, W. O., Guerri, J., Flores, R., and Moreno, P. 1999. New defective RNAs from citrus tristeza virus: Evidence for a replicase-driven template switching mechanism in their generation. J. Gen. Virol. 80:817821.

3. Bandyopadhyay, R., and Frederiksen, R. A 1999. Contemporary global movement of emerging plant diseases. Ann. N.Y. Acad. Sci. 894:28-36.

4. Bar-Joseph, M., Marcus, R., and Lee, R. F. 1989. The continuous challenge of Citrus tristeza virus control. Annu. Rev. Phytopathol. 27:291-316.

5. Barthe, G. A., Ceccardi, T. L., Manjunath, K. L., and Derrick, K. S. 1998. Citrus psorosis vi rus: Nucleotide sequencing of the coat protein gene and detection by hybridization and RTPCR. J. Gen. Virol. 79:1531-1537.

6. Che, X., Mawassi, M., and Bar-Joseph, M 2002. A novel class of large and infectious defective RNAs of Citrus tristeza virus. Virology 298:133-145.

7. D’Urso, F., Ayillon, M. A., Rubio, L., Sambade, A., Hermoso de Mendoza, A., Guerri, J., and Moreno, P. 2000. Contribution of uneven distribution of genomic RNA variants of Citrus tristeza virus (CTV) within the plant to changes in the viral population following aphid transmission. Plant Pathol. 49:288.

8. Fauquet, C. M., Mayo, M. A., Maniloff, J., Desselberger, U., and Ball, L. A. 2005. Virus Taxonomy: Eighth Report of the International Committee on the Taxonomy of Viruses. Academic Press, New York.

9. Garcia, M. L., Sanchez De La Torre, M. E., Dal Bo, E., Djelouah, K., Rouag, N., Luisoni, E., Milne, R. G., and Grau, O. 1997. Detection of citrus psorosis-ringspot virus using RT-PCR 
and DAS-ELISA. Plant Pathol. 46:830-836.

10. Gillings, M., Broadbent, P., Indsto, J., and Lee, R. 1993. Characterisation of isolates and strains of citrus tristeza closterovirus using restriction analysis of the coat protein gene amplified by the polymerase chain reaction. J. Virol. Methods 44:305-317.

11. Huang, Z., Rundell, P. A., Guan, X., and Powell, C. A. 2004. Detection and isolate differentiation of Citrus tristeza virus in infected field trees based on reverse transcriptionpolymerase chain reaction. Plant Dis. 88:625629.

12. Hung, T. H., Wu, M. L., and Su, H. J. 2000. A rapid method based on the one-step reverse transcriptase-polymerase chain reaction (RTPCR) technique for detection of different strains of Citrus tristeza virus. J. Phytopathol. 148:469-475

13. Kong, P., Rubio, L., Polek, M., and Falk, B. W. 2000. Population structure and genetic diversity within California Citrus tristeza virus (CTV) isolates. Virus Genes 21:139-145.

14. Legarreta, G. G., Garcia, M. L., Costa, N., and Grau, O. 2000. A highly sensitive heminested RT-PCR assay for the detection of citrus psorosis virus targeted to a conserved region of the genome. J. Virol. Methods 84:15-22.

15. Lin, Y., Rundell, P. A., Xie, L., and Powell, C. A. 2000. In situ immunoassay for detection of Citrus tristeza virus. Plant Dis. 84:937-940.

16. Martín, S., Alioto, D., Milne, R. G., Garnsey, S. M., Laura García, M., Grau, O., Guerri, J., and Moreno, P. 2004. Detection of Citrus psorosis virus by ELISA, molecular hybridization, RT-PCR and immunosorbent electron microscopy and its association with citrus psorosis disease. Eur. J. Plant Pathol. 110:747-757.

17. Mathews, D. M., Riley, K., and Dodds, J. A. 1997. Comparison of detection methods for Citrus tristeza virus in field trees during months of nonoptimal titer. Plant Dis. 81:525529.

18. Mawassi, M., Gafny, R., and Bar-Joseph, M. 1993. Nucleotide sequence of the coat protein gene of Citrus tristeza virus: Comparison of biologically diverse isolates collected in Israel. Virus Genes 7:265-275.

19. Mawassi, M., Karasev, A. V., Mietkiewska, E., Gafny, R., Lee, R. F., Dawson, W. O., and BarJoseph, M. 1995. Defective RNA molecules associated with Citrus tristeza virus. Virology
208:383-387

20. Mawassi, M., Mietkiewska, E., Hilf, M. E., Ashoulin, L., Karasev, A. V., Gafny, R., Lee, R. F., Garnsey, S. M., Dawson, W. O., and BarJoseph, M. 1995. Multiple species of defective RNAs in plants infected with Citrus tristeza virus. Virology 214:264-268.

21. Mehta, P., Brlansky, R. H., Gowda, S., and Yokomi, R. K. 1997. Reverse-transcription polymerase chain reaction detection of Citrus tristeza virus in aphids. Plant Dis. 81:10661069.

22. Narvaez, G., Skander, B. S., Ayllon, M. A., Rubio, L., Guerri, J., and Moreno, P. 2000. A new procedure to differentiate Citrus tristeza virus isolates by hybridization with digoxigenin-labelled cDNA probes. J. Virol. Methods 85:83-92.

23. Niblett, C. L., Genc, H., Cevik, B., Halbert, S., Brown, L., Nolasco, G., Bonacalza, B., Manjunath, K. L., Febres, V. J., Pappu, H. R., and Lee, R. F. 2000. Progress on strain differentiation of Citrus tristeza virus and its application to the epidemiology of citrus tristeza disease. Virus Res. 71:97-106.

24. Nikolaeva, O. V., Karasev, A. V., Garnsey, S. M., and Lee, R. F. 1998. Serological differentiation of the Citrus tristeza virus isolates causing stem pitting in sweet orange. Plant Dis. 82:1276-1280.

25. Nolasco, G., de Blas, C., Torres, V., and Ponz, F. 1993. A method combining immunocapture and PCR amplification in a microtiter plate for the detection of plant viruses and subviral pathogens. J. Virol. Methods 45:201-218.

26. Olmos, A., Bertolini, E., and Cambra, M. 2002. Simultaneous and co-operational amplification (Co-PCR): A new concept for detection of plant viruses. J. Virol. Methods 106:5159.

27. Olmos, A., Cambra, M., Esteban, O., Gorris, M. T., and Terrada, E. 1999. New device and method for capture, reverse transcription and nested PCR in a single closed-tube. Nucleic Acids Res. 27:1564-1565.

28. Osman, F., and Rowhani, A. 2006. Application of a spotting sample preparation technique for the detection of pathogens in woody plants by RT-PCR and real-time PCR (TaqMan). J. Virol. Methods 133:130-136.

29. Permar, T. A., Garnsey, S. M., Gumpf, D. J., and Lee, R. F. 1990. A monoclonal antibody that discriminates strains of Citrus tristeza virus. Phytopathology 80:224-228.

30. Polek, M., Metheney, M. D., and Wallen, C. 2004. Dubious optical density readings in ELISA testing for Citrus tristeza virus in mandarin varieties of citrus. (Abstr.) Phytopathology 94:S85.

31. Rocha-Pena, M. A., and Lee, R. F. 1991. Serological techniques for detection of Citrus tristeza virus. J. Virol. Methods 34:311-331.

32. Roistacher, C. N. 1993. Psorosis-a review. Pages 139-154 in: Proc. 12th Conf. Int. Org. Citrus Virologists. P. Moreno, J. V. da Graça, and L. W. Timmer, eds. IOCV, Riverside, CA.

33. Rott, M. E., and Jelkmann, W. 2001. Characterization and detection of several filamentous viruses of cherry: Adaptation of an alternative cloning method (DOP-PCR), and modification of an RNA extraction protocol. Eur. J. Plant Pathol. 107:411-420.

34. Roy, A., Fayad, A., Barthe, G., and Brlansky, R. H. 2005. A multiplex polymerase chain reaction method for reliable, sensitive and simultaneous detection of multiple viruses in citrus trees. J. Virol. Methods 129:47-55

35. Rubio, L., Ayllon, M. A., Kong, P., Fernandez, A., Polek, M., Guerri, J., Moreno, P., and Falk, B. W. 2001. Genetic variation of Citrus tristeza virus isolates from California and Spain: Evidence for mixed infections and recombination. J. Virol. 75:8054-8062.

36. Salomone, A., Mongelli, M., Roggero, P., and Boscia, D. 2004. Reliability of detection of Citrus tristeza virus by an immunochromatographic lateral flow assay in comparison with ELISA. J. Plant Pathol. 86:43-48

37. Sambade, A., Lopez, C., Rubio, L., Flores, R., Guerri, J., and Moreno, P. 2003. Polymorphism of a specific region in gene p23 of Citrus tristeza virus allows discrimination between mild and severe isolates. Arch. Virol 148:2325-2340.

38. Timmer, L. W., Garnsey, S. M., and Graham, J. H., eds. 2000. Compendium of Citrus Diseases, 2nd ed. American Phytopathological Society, St. Paul, MN

39. Zanek, M. C., Pena, E., Reyes, C. A., Figueroa, J., Stein, B., Grau, O., and Garcia, M. L. 2006. Detection of Citrus psorosis virus in the northwestern citrus production area of Argentina by using an improved TAS-ELISA. J. Virol. Methods 137:245-251. 